\title{
Evaluation on Red Pepper Germplasm lines (Capsicum spp.) for Resistance to Anthracnose Caused by Colletotrichum acutaum
}

\author{
Jeong-Soon Kim ${ }^{1}$, Hyeong-Jin Jee ${ }^{2}$, Jae-Gyun Gwag ${ }^{1}$, Chung-Kon Kim ${ }^{1}$ and Chang-Ki Shim ${ }^{1 *}$ \\ ${ }^{\prime}$ National Agrobiodiversity Center and ${ }^{2}$ Organic Farming Technology Division, National Academy of Agricultural Science and \\ Technology, Rural Development Administration, Suwon 441-707, Korea
}

(Received on January 31, 2010; Accepted on June 29, 2010)

We evaluated 209 Capsicum accessions from the National Agrobiodiversity of RDA, for their reaction against of anthracnose disease caused by Colletotrichum acutatum. Two hundred nine accessions of Capsicum were almost composed with Capsicum annuum var. annuum originated from 37 countries. The percentage of infection due to $C$. acutatum ranged from $11.1 \%$ to $100 \%$ on immature and matured pepper fruits at 21 days after inoculation. On immature fruits of pepper, one hundred seventy three accessions of tested pepper were found infected with $C$. acutatum. Out of the 173 accessions, eighty five accessions were susceptible to anthracnose with dark brown to black lesions and slowly increased in size at 21 days after inoculation. Only thirty six accessions showed resistance against $C$. acutatum. On mature fruits of pepper, one hundred ninety eight accessions were infected with $C$. acutatum at 21 days after inoculation. Twenty one accessions showed a resistance reaction against $C$. acutatum. The results of this work indicated that all of resistance accessions to $C$. acutatum were have a genetic potential for the resources of resistance can be further used in pepper breeding programme against anthracnose and also demand more detailed investigation in this.

Keywords : anthracnose, capsicum, Colletotrichum acutatum, resistance

Chilli or red pepper is a commonly grown as an herbaceous annual dicotyledonous flowing plant in temperate areas (Bosland, 1996). Chilli belongs to members of the genus Capsicum, twenty five species, have been cultivated extensively, initially in the Americas and, later spread to European contact, throughout the worldwide (Eshbaugh, 1993; Heiser, 1976) is being used as a food flavoring, a coloring agent, a pharmaceutical ingredient, and in other innovative ways (Bosland, 1994; Cronin, 2002; Hoffman et al., 1983; Krishna De, 2003; Wall and Bosland, 1993; Woodbury,

\footnotetext{
*Corresponding author.

Phone)+82-31-299-1878, FAX)+82-31-299-1893

E-mail)ckshim@korea.kr
}

1980). Numerous cultivars within the five domesticated species, Capsicum annuum, $C$. frutescens, $C$. chinense, $C$. baccatum and $C$. pubescens, have been grown exponentially (Heiser and Smith, 1953; Heiser, 1985; IBPGR, 1983; Smith and Heiser, 1957; Tong and Bosland, 1999; Yoon et al., 2004).

It is estimated that the Capsicum agribusiness is worth about $4 \%$ of gross agricultural production in Korea (Kwon et al., 2006). But, the main problems being faced by growers are the problems of managing diseases and few insect pests (Kim and Park, 1988; Um, 1998; SAGARPA, 2002).

Anthracnose, caused by various species of Colletotrichum spp. cause significant damage to a wide range of crops including pepper, strawberry, grapevine and apple (Berstein et al., 1995; Freeman and Katan, 1997; Hadden and Black, 1988; Kim and Nam, 1999; Park and Kim 1992). Especially, anthracnose is one of the major production constraints, due to loss more than $10 \%$ of the total annual pepper production, estimated to be more than 100 million US dollars, including Korea (Park and Kim 1992; Manadhar et al., 1995; Poonpolgul and Kumphai, 2007; Shin et al., 1999; Um, 1998). Typical anthracnose symptoms on pepper fruit include sunken necrotic tissues, with concentric rings of acervuli. Fruits showing blemishes have reduced marketability (Manandhar et al., 1995).

In Korea, four anamorphic species, Colletotrichum acutatum, C. cocodes, C. dematium, and C. gloeosporioides, and one teleomorphic species, Glomerella cingulata have been described as the causal agents of pepper anthracnose symptoms (Hong and Hwang, 1998; Kim et al., 1986; Kim et al., 2007; Park and Kim 1992). Among these, $C$. acutatum was currently reported as the dominant pathogens in Korea (Kim et al., 2008).

This study was carried out to evaluate resistance against anthracnose disease in pepper germplasm lines and to provide information on resistant sources for improving the efficiency of Chilli pepper breeding. For this purpose 209 accessions of three Capsicum species, Capsicum annuum var. annuum, $C$. frutescens and $C$. pubescens, from the National Agrobiodiversity Center of RDA, Korea, were 
screened against $C$. acutatum in Table 1. Ten pepper seeds of each accession were disinfected with $2 \% \mathrm{NaOCl}$ for 4 hrs and washed with tap water at several times and pregerminated on the moist filter paper in petri-dish at $30^{\circ} \mathrm{C}$ for one-week in light condition. Pre-germinated pepper seeds are then transplanted in peat moss artificial soil and pepper seedlings are grown for 21-25 days in the green house. Transplants are kept clean by managing weeds with mulching of black polyvinyl films. None of the pepper fields were sprayed with any types of fungicides. The pepper fruits were harvested at fruit breaker stage from immature-green to mature-red.

Based on conidia size, morphology, and pahogenicity, the isolates obtained from the pepper fruits were identified as either C. gloeosporioides or C. acutatum (Verma, 1973). The major population consists of the isolates of $C$. gloeosporioides in the late 1980th (Park and Kim, 1992), and recently $C$. acutatum was identified as a major pathogen in Korea pepper fields.

The dominant strain of anthracnose pepper disease, Colletotrichum acutatum KACC40042 (Kim et al., 2006; Wei et al., 2008), was obtained from Korean Agricultural Culture Collection (KACC, Rural Development Adminstration (RDA), Suwon, Korea. The anthracnose pathogen was grown on Potato Dextrose Agar (PDA) at $25^{\circ} \mathrm{C}$ under fluorescent lights. The conidia are harvested by placing 10 $\mathrm{ml}$ of sterilized distilled water onto 7 days old cultures, by scraping the surface of the media with an inoculating loop to release the conidia from the hyphae. Later added $10 \mathrm{ml}$ of conidial suspension into a $500 \mathrm{ml}$ of autoclaved new PDA medium, and poured approximately the medium into 30 sterile Petri plates. The plates were incubated for two days for mycelium grown on PDA medium under dark condition and later, induced the formation of perithecia for five days under light condition. An agar disk, $4 \mathrm{~mm}$ diameter was cut with a Cork borer from an actively growing of perithecial inoculums on the PDA medium.

We modified the inoculation methods for inoculums concentration, microdropping, high-pressure spraying, pinning, and microinjection as described by previous studies (Choi and Pae, 1987; Hong and Hwang, 1998; Pae et al.,
1998; Yoon and Park, 2001).

The outbreak of the pepper anthracnose has severely decreased the pepper production. Thus, it is very important to identify the major pathogen of the pepper anthracnose for early diagnosis and the disease management in the fields, because each Colletotrichum species shows significant variation in the response to the host diversity of Capsicum varieties (Kim et al., 2008; Park and Kim, 1992).

The detached healthy fruits harvested from the pepper plants in a greenhouse were used for determining the resistance of each accession against the pathogens. Fruits were surface-sterilized in a 2,000 ppm NaDCC (Sodium Dichloroisocyanurate) solution for $30 \mathrm{~min}$., rinsed in tap water and in sterile water for several times and placed on the sterile paper towel and then air dried. The surface sterilized fruits are wounded by a pin-pricking of the appliance (Accu-Chek Softclix) used for measuring the blood sugar and inoculated by placing $5 \mathrm{~mm}$ diameter of perithecia agar disk. Control fruits are inoculated with PDA disk (Choi and Pae, 1987). The inoculated fruits are incubated in a Lock \& Lock container $(21 \times 28 \times 9 \mathrm{~cm})$ with high relative humidity $(100 \%)$ at $22.5-27.5^{\circ} \mathrm{C}$ in normal light regimes and evaluated for disease reaction at weekly interval for three weeks after inoculation.

Evaluation of anthracnose symptoms such as lesion appearance, lesion size and the severity of infection was carried out from 7 to 21 days after inoculation. Lesion development of three fruits of immature (green) and matured (red) pepper of each accessions are assessed by the average percentage of diseased on each fruit by weekly checking for disease development.

In the present study, two hundred nine accessions of Capsicum were composed with 198 accession of $C$. annuum var. annuum, 10 accessions of $C$. frutescens and one accession of $C$. pubescens, originated from 37 countries including Korea and are preserved in the National Agrobiodiversity Center of RDA, Korea (Table 1).

The United States National Plant Germplasm System preserve an extensive Capsicum germplasm collection at the Southern Plant Introduction Experiment Station located in, Georgia. This collection consisted of approximately 3000

Table 1. Diversity of two hundred and nine accessions of Capsicum germplasms for the evaluation of resistance against anthracnose disease in this study

\begin{tabular}{ll}
\hline \hline \multicolumn{1}{c}{ Species } & \multicolumn{1}{c}{ Origins } \\
\hline Capsicum annuum var. & AFG(1), ARM(1), BGR(5), BOL(2), CAN(2), CHN(8), CSK(1), CZE(1), EGY(1), GEO(1), GTM(1), \\
annuum (198) & HUN(5), IDN(1), IND(1), ISR(2), KOR(95), LAO(4), MDA(1), MEX(2), MYS(3), NPL(6), PAK(1), \\
\hline Capsicum frutescens (10) & LAO(8), MEX(1), TWN(1) \\
\hline Capsicum pubescens (1) & GTM(1) \\
\hline
\end{tabular}



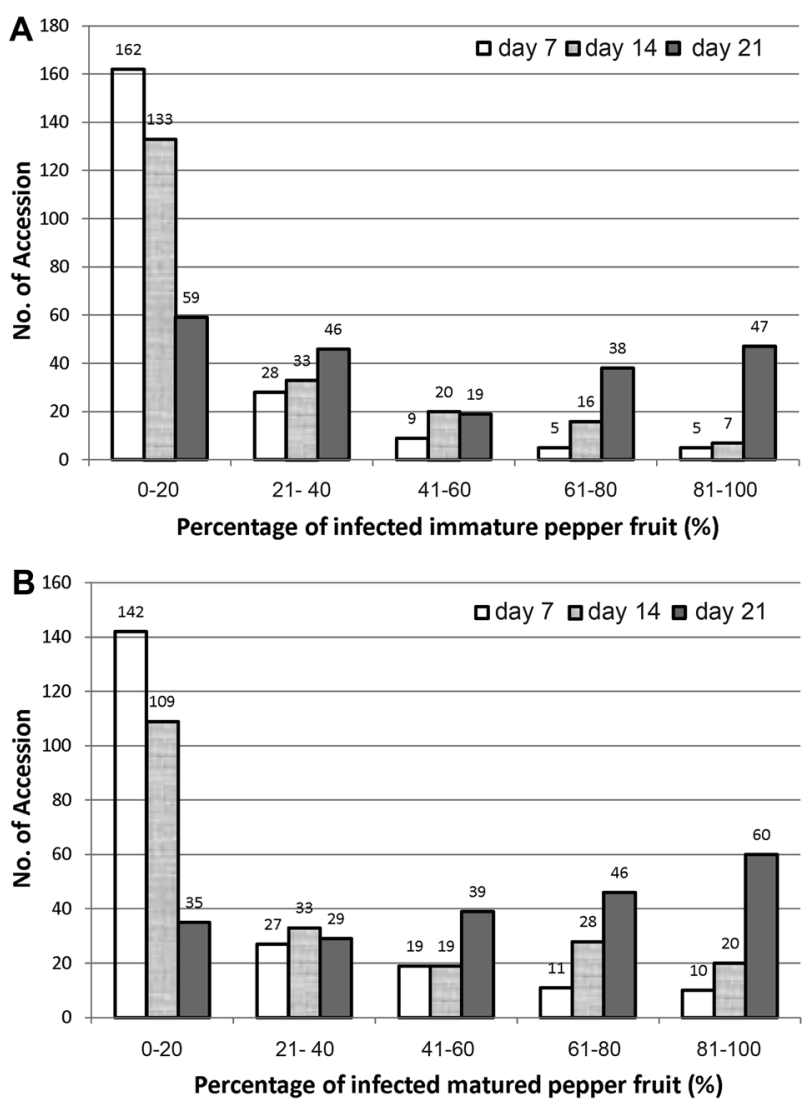

Fig. 1. Comparison of anthracnose resistance of pepper with immature (A) and matured (B) fruit of Capsicum germplasms at an interval of one week after inoculation with Colletotrichum acutatum at room temperature and under saturated humidity.

Capsicum accessions that include lines from all over the world (Bosland, 1996). A total of 225 accessions from eight Capsicum species preserved at the AVRDC (Asian Vegetable Research and Development Center) were characterized using thirty seven morphological traits and were utilized a useful sources in the breeding of improved pepper cultivars adapted to subtropical and temperate regions (Chae et al., 2003).

The percentage of infection with $C$. acutatum ranged from $11.1 \%$ to $100 \%$ on both immature and matured pepper fruits at 21 days after inoculation (Fig. 1). The initial sunken symptoms were formed 7 days after inoculation on susceptible accessions and later these lesions increased in size, coalesced with other lesions leading to increased size on fruits (Fig. 3).

On immature fruits of pepper, one hundred seventy three accessions of tested pepper germplasm lines are infected with $C$. acutatum. Of the 173 accessions, eighty five accessions were susceptible to anthracnose disease and were scored from $60.1 \%$ to $100 \%$ and caused dark brown to black lesions and slowly increased in size at 21 days after
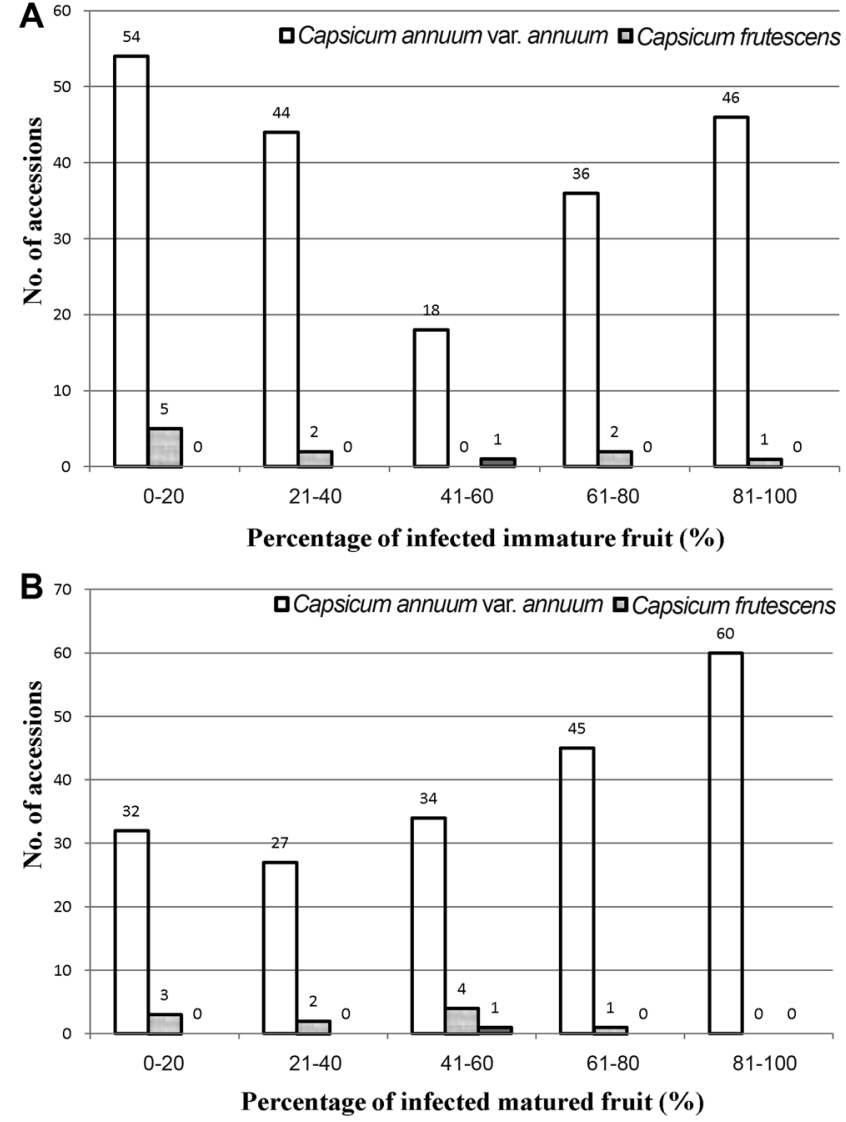

Fig. 2. Distribution of percentage ranges of infected immatured (A) and matured (B) fruit on Capsicum species for the evaluation of resistance against anthracnose disease caused by Colletotrichum acutatum at 21 days after inoculation.

inoculation (Fig. 1, A). However, thirty six accessions have shown resistance against $C$. acutatum and composed with thirty five accessions of Capsicum annuиm var. anпиит and one accessions of $C$. frutescens (Fig. 2, A).

On mature fruits of pepper, one hundred ninety eight accessions of tested pepper germplasm were found infected with $C$. acutatum at 21 days after inoculation. One hundred six accessions of infected pepper fruit produced more severe symptoms and scored from $60.1 \%$ to $100 \%$ (Fig. 1, B). In all of susceptible accessions the lesions increased in size, coalesced and damaged the entire fruit. Twenty one accessions have shown a resistance against $C$. acutatum and composed with ten accessions of Capsicum annuum var. annuum and one accessions of $C$. frutescens (Fig. 2, B).

Pepper anthracnose mainly damages immature green and matured red fruits and leaves as lesions. Thus, production in the tropics has serious disease and quality problems, which could be solved if the genetic diversity is rationally used in breeding programs. C. gloeosporioides attacks pepper fruits at both the green and red stage, while $C$. capsici mainly 

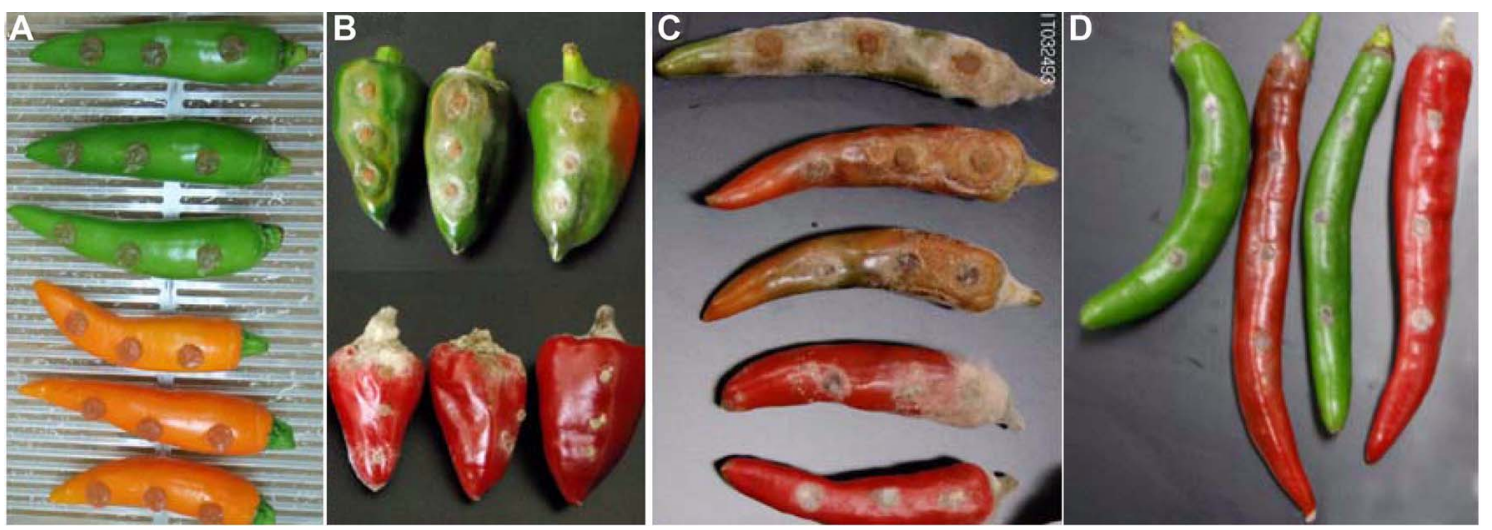

Fig. 3. Comparison of disease sympotoms developed on susceptible and resistant Capsicum accessions. Typical symptoms developed on accession of C. anmuum, anthracnose disease caused by Colletotrichum acutatum at 21 days after inoculation. A, 7 days after inoculation; $\mathrm{B}, \mathrm{C}$, susceptible reaction; $\mathrm{D}$, resistance reaction.

attacks pepper fruits at the red stage (Park et al., 1989; Park et al., 1990).

Thirty accessions of Capsicum annuum var. annuum and two accessions of $C$. frutescens showed complete resistance to C. acutatum in both immature and matured fruits (Fig. 2). The microscopic examination of susceptible cultivar revealed the surface and inner tissue of susceptible pepper fruits with pin-prick wounding, showed the typical symptoms, the mycelial growth and the propagation of acervuli and conidia (Fig. 4, B, D, F, and H). One the other hand, the resistant pepper fruits were devoid of such symptoms and mycological development on the pin-prick wounding tissue inoculated with the pathogen (Fig. 4, A, C, E, and G).

The five variously domesticated species are Capsicum annuum, $C$. frufescens, $C$. chinense, $C$. baccatum and $C$. pubescus. Capsicum annuum, $C$. frufescens, $C$. chinense are grouped in a taxonomic complex which has conventionally three, or perhaps two or one species (Pickersgill, 1988), with the three clusters of domesticated plants appearing to be more divergent than their wild progenitors (Bosland and Votava, 2000; Baral and Bosland, 2004; Eshbaugh, 1993; Heiser, 1985; Jarret and Dang, 2004; Idu and Ogbe, 1997; Park et al., 1999; Prince et al., 1995; Ry Zlova and Kochieva, 2004; Walsh and Hoot, 2001).

Capsicum pepper in Korea has a very narrow genetic base due to restricted consumer preferences with the exception of a few cultivars grown for their fresh fruits, almost all cultivars are cultivated for dried red fruits with varying degrees of pungency.

C. baccatum and C. pubescu are in other taxonomic complexes of the genus and little used beyond Latin America, although C. baccatum var. pendalum (wild). Eshbaugh, the variety that has been extensively domesticated chilli peppers. So in some literature caution is needed to ascertain whether the plants discussed are actually $C$.

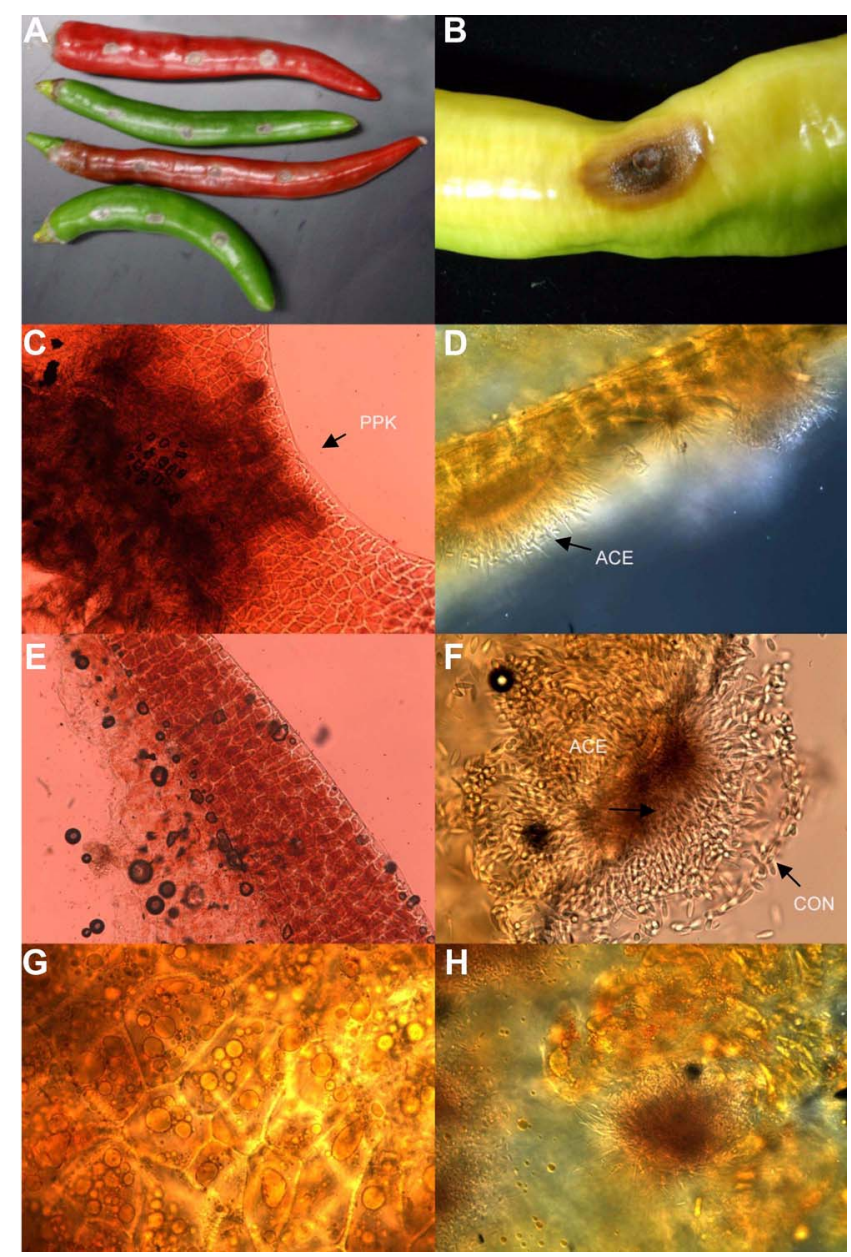

Fig. 4. The microscopic examination of resistant (left, A, C, E, and $\mathrm{G}$ ) and susceptible (right, B, D, F, and H) pepper fruits with pin-prick wounding (PPK) in Capsicum germplasm. Typical symptoms developed on accession of $C$. annuum, anthracnose disease caused by Colletotrichum acutatum at 21 days after inoculation. ACE, Acervulus; CON, Conidia; PPK, pin-prick wounding site 
annuum or $C$. frutescens itself or another of these species (Heiser and Pickersgill, 1969; Heiser, 1985).

In the species, $C$. annuum throughout the world, horticultural, agricultural and biological diversity has helped to make globally important crop as a fresh and cooked vegetable and a source of food ingredients for sauces and powders and as a colorant, which is used as well in cosmetics (Andrews, 1995, 1999; Bosland, 1994; Bosland and Votava, 2000).

Recently, it was found that a local Korean variety, $C$. annuum 'Daepong-cho', had resistance to $C$. capsici. Inheritance of resistance to $C$. capsici was analyzed in segregating population derived from 'Yeoju' $\times$ 'Daepoongcho' and 'AR' $\times$ 'Daepoong-cho'. Out of the two lines, the resistance of 'Daepoong-cho' to $C$. capsici is controlled by a single recessive gene (Kim et al., 2008).

Several sources of resistance to $\mathrm{C}$. capsici have been reported and, using these resources, researchers have studied the inheritance of anthracnose resistance (Cheema et al., 1984; Lin et al., 2002; Park et al., 1990; Pakdeevaraporn et al., 2005; Voorrips et al., 2004).

Anthracnose disease is one of the major economic constraints to pepper production worldwide, especially in tropical and subtropical regions. Accurate taxonomic information is necessary for effective disease control management. In the Colletotrichum patho-system, different Colletotrichum species can be associated with anthracnose of the same host (Park et al., 1989; Kim et al., 2004; Lin et al., 2004; Marin et al., 2004).

Management of the pepper anthracnose has been solely dependent upon the application of fungicides due to lack of resistant pepper cultivars (Hadden and Black, 1986; Manandhar et al., 1995).

Since 1980, Embrapa's National Research Center for vegetable crops has conducted a pepper breeding program aiming at demands from different market niches. The program traditionally emphasizes the development of hot and source specific sweet pepper populations, lines, cultivars, and hybrids with multiple disease resistance and high quality fruits, benefiting from a large gene bank of genotypes native to Brazil and also introduced from abroad (Ribeiro et al., 2008). In conclusion, 40 pepper germplasm accessions in immature fruits category and 25 accessions in mature fruit category showing resistance be further explored in contemporary durable resistance breeding programme for enhancing both disease resistance and quality of red pepper in Korea.

\section{Acknowledgements}

This work was supported by a grant program funded by Rural Development Administration (200901FHTO20609
50301) and the National Research Foundation of Korea Grant funded by the Korean Government (NRF-2009-351F00030), Republic of Korea in 2009.

\section{References}

Andrews, J. 1995. Peppers: The domesticated Capsicums, new, ed., University of Texas Press. Austin, USA. 186 p.

Andrews, J. 1999. The Pepper Trail: History and recipes from around the world. University of North Texas Press. Texas, USA. 261 p.

Barla, J. B. and Bosland, P. W. 2004. Unraveling the species dilemma in Capsicum frutescens and C. Chinense (Solanaceae): A multiple evidence approach using morphology. Molecular analysis and sexual compatibility. J. American Soc. Hor. Sci. 129:826-832.

Berstein, B., Zehr, E. I., Dean, R. A. and Shabi, E. 1995. Characteristics of Colletotrichum from peach, apple, pecan, and other hosts. Plant Dis. 79:478-482.

Bosland, P. W. 1994. Chiles: history, cultivation, and uses. pp. 347-366. In: G Charalambous, ed., Spices, herbs, and edible fungi. Elsevier Publ., New York.

Bosland, P. W. 1996. Capsicums: Innovative uses of an ancient crop. pp. 479-487. In: J. Janick, ed., Spices, herbs, and edible fungi. Elsevier Publ., New York.

Bosland, P. W. and Votava, E. J. 2000. Peppers: Vegetable and spice Capsicums. Crop Production Science in Horticulture 12. CAB. International Publishing, Wallingford, England, UK. $204 p$.

Chae, Y., Shieh, J. C., Park, J. B. and Engle, L. M. 2003. Morphological evaluation of Capsicum germplasm using statistic analysis. Kor. J. Hort. Sci. Technol. 21(Suppl. II):63.

Cheema, D. S., Singh, D. P., Eawal, R. D. and Deshpande, A. A. 1984. Inheritance of resistance to anthracnose disease in chillies. Capsicum Newsletter 3, $44 \mathrm{p}$

Choi, K. S. and Pae, D. H. 1987. Studies on the breeding of resistant varieties of pepper 3. Study on the inoculation methods for resistant varieties of pepper to anthracnose. Rural Dev. Administration (Hort.) 29:16-23.

Collins, M. D., Mayer-Wasmund, L. and Bosland, P. W. 1995. Improved method for quantifying capsaicinoids in Capsicum using high performance liquid chromatography. HortScience 30:137-139.

Cronin, J. R. 2002. The Chili peppers pungent principle: Capsaicin delivers diverse health benefits. Alternative and Complementary Therapies 8:110-113.

Eshbaugh, W. H. 1993. Peppers: History and exploitation of a serendipitous new crop discovery. In J. Jack and J. E. Simon eds, New Crops, pp. 132-139. John Wiley \& Sons, New York, USA.

Freeman, S. and Katan, T. 1997. Identification of Colletotrichum species responsible for anthracnose and root necrosis of strawberry in Israel. Phytopathology 87:516-521.

Freeman, S., Katan, T. and Shabi, E. 1998. Characteristics of Colletotrichum species responsible for anthracnose disease of various fruits. Plant Dis. 82:596-605. 
Hadden, J. F. and Black, L. L. 1988. Anthracnose of pepper caused by Colletotrichum spp. pp. 189-199. In: Tomato and Pepper production in Tropics. S. K. Green, ed., AVRDC, Shanhua, Taiwan.

Heiser, Jr. C. B. 1976. Peppers: Capsicum (Solanaceae). In: N. W. Simmonds, ed., Evolution of Crop plants, pp. 265-268. Longman, London, UK.

Heiser, Jr. C. B. 1985. Ethnobotany of the naranjilla (Solanum quitoense) and its relatives. Economic Botany 39:4-11

Heiser, Jr. C. B. and Pickersgill, B. 1969. Names for the cultivated Capsicum species (Solanaceae). Taxon 18:277-283.

Heiser, Jr. C. B. and Smith P. C. 1953. The cultivated Capsicum peppers. Eco. Bot. 1:214-227.

Hoffman, P. G, Lego, M. C. and Galetto, W. G. 1983. Separation and quantitation of red pepper major heat principles by reverse-phase high pressure liquid chromatography. J. Agr. Food Chem. 31:1326-1330.

Hong, J. K. and Hwang, B. K. 1998. Influence of inoculums density, wetness duration, plant age, inoculation method, and cultivar resistance on infection of pepper plants by Colletotrichum cocodes. Plant Dis. 82:1079-1083.

IBPGR. 1983. Genetic resources of Capsicum. In: Board for plant Genetic Resources, Rome.

Idu, M. and Ogbe, T. M. 1997. Studies on the morphology of Capsicum species. J. Plant Anatomy and Morphology 7:114123.

Jarret, R. L. and Dang, P. 2004. Revisiting the waxy locus and the Capsicum annum L. complex. Georgia. J. of Science 62:117133.

Kim D. H., Jeon, Y. A., Go, S. J., Lee, J. K. and Hong, S. B. 2006. Reidentification of Colletotrichum gloeosporioides and $C$. acutatum isolates stored in Korean Agricultural Culture Collection (KACC). Res. Plant Dis. 12:168-177.

Kim, C. H. and Park, K. S. 1998. A predictive model of disease progression of red-pepper anthracnose. Korean J. Plant Pathol. 4:325-331.

Kim, H. G and Nam, M. H. 1999. Anthracnose of strawberry in Korea. Plant Dis. Agric. 5:8-13.

Kim, J. T., Park, S. Y., Choi, W. B., Lee, Y. H. and Kim, H. T. 2008. Characterization of Colletotrichum isolates causing anthracnose of pepper in Korea. Plant Pathol. J. 24:17-23.

Kim, K. K., Yoon, J. B., Park, H. G., Park, E. W. and Kim, Y. H. 2004. Structural modifications and programmed cell death of chili pepper fruits related to resistance responses to Colletotrichum gloeosporioides infection. Genetics and Resistance. 94:1295-1304.

Kim, S. T., Yoon, J. B., J. W. and Park, H. G. 2008. A major recessive gene associated with anthracnose resistance to Colletotrichum capsici in chili pepper (Capsicum annuum L.). Breeding Science 58:137-141.

Kim, W. G., Cho, E. G and Lee, E. J. 1986. Two strains of Colletotrichum gloeosporioides Prnz. causing anthracnose of pepper fruits. Kor. J. Plant Pathol. 2:107-113.

Kim, Y. S., Min, J. Y., Kang, B. K., Bach, N. V., Choi, W. B., Park, E. W. and Kim, H. T. 2007. Analysis of the less benzimidazole-sensitivity of the isolates of Colletotrichum spp. caus- ing the anthracnose in Pepper and Strawberry. Plant Pathol. J. 23:187-192.

Kwon, T. R., Pae, D. H., Shin, Y. A., Oh, D. G. and Lee, J. M. 2006. Capsicum Peppers: A Vital Crop for Korea. Chronica Horticulturae 46:16-19.

Krishna De, A. 2003. Capsicum: The genus Capsicum. Medicinal and aromatic plants-industrial profiles Vo. 33. Taylor \& Francis, London and New York, $275 \mathrm{p}$.

Lin, Q., Kanchana-udomkarn, C., Jaunet, T. and Mongkolporn, O. 2002. Genetic analysis of resistance to pepper anthracnose caused by Colletotrichum capsici. Thai J. Agricultural Sci. 35:259-264.

Manandhar, J. B., Hartman, G L. and Wang, T. C. 1995. Anthracnose development on pepper fruits inoculated with Colletotrichum gloeosporioides. Plant Dis. 79:380-383.

Marin, A., Ferreres, F. F., Tomáa Barberán, F. A. and Gil, M. 2004. Characterization and quantitation of antioxidant constituents of sweet pepper (Cpasicum annuum L.). J. Agr. Food Chemistry 52:3861-3869.

Ministry of Food, Agriculture, Forestry and Fisheries. 2008. Agricultural and Forestry Statistical Yearbook.

Oh, I. S., In, M. S., Woo, I. S., Lee, S. K. and Yu, S. H. 1988. Anthracnose of Pepper seedling caused by Colletotrichum coccodes (Wallr.) Hughes. Kor. J. Mycol. 16:151-156.

Osuna-García, J. A., Wall, M. W. and Waddell, C. A. 1998. Endogenous levels of tocopherols and ascorbic acid during fruit ripening of New Mexican-typing Chile (Cpasicum anmum L.) cultivars. J. Agr. Food Chemistry 46:5093-5096.

Pae, D. H., Chae, Y. T., Wang, C. and Engle, L. M. 2003. Selection of new breeding materials with resistant to anthracnose in Capsicum annumm. Kor. J. Hort. Sci. Technol. 21 (Supp. II): 63.

Pae, K. S., Yoon, J. Y. and Lee, J. M. 1998. Screening for resistance to Colletotrichum gloeosporioides using detached fruits in pepper (Capsicum annuum) by high-pressure spray. J. Kor. Soc. Hort. Sci. 39:690-692.

Pakdeevaraporn, P., Wasee, S., Taylor, P. W. J. and Mongkolporn, O. 2005. Inheritance of resistance to anthracnose caused by Colletotrichum capsici in Capsicum. Plant Breeding. 124:206208.

Park, H. K., Kim, B. S. and Lee, W. S. 1990. Inheritance of resistance to anthracnose (Colletotrichum spp) in pepper (Capsicum annuиm L.) II. Genetic analysis of resistance to Colletotrichum dematium. J. Kor. Soc. Hort. Sci. 31:207-212.

Park, K. S. and Kim, C. H. 1991. Five fungal species associated with anthracnose of red pepper in Korea. Phytopathology $81: 1135$.

Park, K. S. and Kim, C. H. 1992. Identification, distribution and etiological characteristics of anthracnose fungi of red pepper in Korea. Korean J. Plant Pathol. 8:61-69.

Park, W. M., Kim, S. H. and Ko, Y. H. 1989. Susceptibilization of a red pepper (Capsicum annuum) to Colletotrichum gloeosporioides Penz. in relation to the ripening of fruits. Kor. J. Plant Pathol. 5:262-270.

Park, Y. K., Kim, B. D., Kim, B. S., Armstrang, K. C. and Kim, N. S. 1999. Keryotyping of the chromosome and physical map- 
ping of the 5S rRNA and 18S-26S rRNA gene families in five different species in Capsicum. Genus \& Genetic systems. 72:149-157.

Pickersgill, B. 1988. The genus Capsicum: A multidisciplinary approach to the taxonomy of cultivated and wild plants. Biologisches Zentralblant 107:381-389.

Poonpolgul, S. and Kumphai, S. 2007. Chilli Pepper anthracnose in Thailand. Country report. In: Oh, D. G and Kim, K. T. eds., p. 23. The first international symposium on Chilli Anthracnose. National Horticultural Research Institute, Rural Development Administration, Korea.

Prince, J. P., Lackney, V. K., Angeles, C., Blauth, J. R. and Kyle, M. M. 1995. A survey of DNA polymorphism within the genus Capsicum and the fingerprinting of Pepper cultivars. Genome 38:224-231.

Redondo, J. E. 1979. Busqueda de genotipos de chile resistance al hange Phytophthora capsici Leonion. Proc. Tropical Region. A. S. H. S. 23:220-224.

Ribeiro, C. S., Boiteux, L. S., Amaro, G B. and Reifschneider, F. J. B. 2008. Capsicum breeding at Embrapa vegetable crops, Brasilia, Brazil. In: Proceedings of the 19th International Pepper Conference, Sep. 7-10, Atlantic City, NJ, USA.

Ryzhova, N. N. and Kochieva, E. Z. 2004. Analysis of microsatellite loci of the chloroplast genome in the genus Capsicum (Pepper). Russian J. Genetics 40:892-896.

SAGARPA. 2002. Programa agrícola de los ciclos 0.1. 2001/ 2002. pv. 2002/2003. Servicio de Información estadística Agroalinentaria presquera (SIAP). Secretaría de Agricultura Ganadería, Desarrollo Rural, Pesca Alimentacion. Página web: www.sagarpa.gob.mx

Shin, H. J., Chen, Z. J., Hwang, J. M. and Lee, S. G. 1999. Comparison of pepper anthracnose pathogens from Korea and China. Plant Pathol. J. 15:323-329.

Smith, P. G and Heiser, C. B. 1957. Taxonomy of Capsicum sinense Jacq. and the geographic distribution of the cultivated
Capsicum species. Bul. Torrey Bot. Club 84:413-420.

Tong, N. and Bosland, P. W. 1999. Capsicum tovarii, a new member of the Capsicum baccatum complex. Euphytica 109:71-77.

Um, K. H. 1998. Conidia germination and appressorium formation of colletotrichum spp. isolate pepper fruits. MS Diss., Seoul National University. p. 93.

Verma, M. L. 1973. Comparative studies on virulence of isolates of species of Colletotrichum parasitic on Chillies. Indian Phytopathology 26:28-31.

Wall, M. M. and Bosland, P. W. 1993. The shelf-life of Chiles and Chile containing products. p. 487-500. In: G Charalambous, ed., Shelf life studies of foods and bebverages, chemical, biological, and nutritional aspects. Elsevier Publishing, New York.

Walsh B. H. and Hoot, S. B. 2001. Phylogenetic relationship of Capsicum (Solanaceae) using DNA sequences from two noncoding regions: The chloroplast $a t p B-r b c l$ spacer region and nuclear waxy introns. Int. J. Plant Sci. 162:1409-1418.

Walter, J. M. 1992. Colletotrichum diseases of perennial and other cash crops. In: Colletotrichum-Biology, Pathology, and Control. J. A. Bailey and M. J. Jeger, ed., pp. 167-185. CAB Intl., Wallingford, United Kingdom.

Wei, X., Jeon, H. S., Han, K. S., Koh, Y. J. and Hur, J. S. 2008. Antifungal activity of lichen-forming fungi against Colletotrichum acutatum on Hot Pepper. Plant Pathol. J. 24:202-206.

Woodbury, J. E. 1980. Determination of Capsicum pungency by high pressure liquid chromatography and spectrofluorometric detection. J. Assn. Offic. Anal. Chem. 63:556-558.

Yoon, J. B. and Park, H. G 2001. Screening method for resistance to pepper fruit anthracnose; Pathogen sporulation, inoculation methods related to inoculums concentrations, and post-inoculation environments. J. Kor. Sco. Hort. Sci. 42:389-393.

Yoon, J. B., Do, J. W., Yang, D. C. and Park, H. G. 2004. Interspecific cross compatibility among five domesticated species of Capsicum genus. J. Korean Soc. Hort. Sci. 45:324-329. 